\title{
The effect of digestible protein to digestible energy ratio and choline supplementation on growth, hematological parameters, liver steatosis and size-sorting stress response in Nile tilapia under field condition
}

\author{
Ademir Calvo Fernandes Junior *, Pedro Luiz Pucci Figueiredo de Carvalho, Luiz Edivaldo Pezzato, \\ João Fernando Albers Koch, Caroline Pelegrina Teixeira, Felipe Tenório Cintra, Flávia Motta Damasceno, \\ Renee Laufer Amorin, Carlos Roberto Padovani, Margarida Maria Barros
}

UNESP, Univ. Estadual Paulista, FMVZ, AquaNutri, Botucatu, SP, Brazil

\section{A R T I C L E I N F O}

\section{Article history:}

Received 29 October 2015

Received in revised form 20 January 2016

Accepted 1 February 2016

Available online 2 February 2016

\section{Keywords:}

Protein sparing effect

Hepatic steatosis

Fish health

Hematology

Intensive system

Economic analysis

\begin{abstract}
A B S T R A C T
This study evaluated growth performance, hematological parameters, histological liver analysis, and production costs of Nile tilapia fed increasing levels of digestible protein, digestible energy, and choline. Twelve thousand Nile tilapia (148 $\pm 6.7 \mathrm{~g}$ ) were randomly distributed into $801 \mathrm{~m}^{3}$ net cages, in a $5 \times 2 \times 2$ factorial design with five digestible protein (DP) levels $(24,26,28,30$, and $32 \% \mathrm{DP})$, two digestible energy (DE) levels (13.4 and $14.65 \mathrm{MJ} \mathrm{DE} \mathrm{kg}{ }^{-1}$ diet), and two choline levels ( 0.0 and $1000 \mathrm{mg} \mathrm{kg}^{-1} \mathrm{diet}$ ), with four replicates per treatment. Fish fed the higher energy level showed a sparing effect of protein; the higher protein level determined the highest fillet yield. Fish fed diets with $24 \%$ DP showed the highest liver lipid, and independently of treatment all analyzed fish showed hepatocyte degeneration. The best benefit cost ratio for whole fish production was achieved with $28 \% \mathrm{DP} / 13.4 \mathrm{MJ} \mathrm{DE} \mathrm{kg} \mathrm{g}^{-1}$, and for fillet production with $30 \% \mathrm{DP} / 13.4 \mathrm{MJ} \mathrm{DE} \mathrm{kg}^{-1}$. The results of the hematological assay showed alterations in red blood cells, mean corpuscular volume, albumin, Albumin:Globulin ratio, and glucose after size-sorting stress. Overall, these results indicate a lower resistance to stress, mainly for fish fed with no choline and oil supplementation. In this study we determined that the best performance was achieved with DP:DE ratios of $21.45 \mathrm{~g} \mathrm{MJ}^{-1}\left(28.74 \% \mathrm{DP} / 13.4 \mathrm{MJ} \mathrm{DE} \mathrm{kg}^{-1}\right) \mathrm{and}^{-1}$ $18.60 \mathrm{~g} \mathrm{MJ}^{-1}\left(27.25 \% \mathrm{DP} / 14.65 \mathrm{MJ} \mathrm{DE} \mathrm{kg}{ }^{-1}\right)$. The highest fillet yield was obtained with 30\% DP, regardless of the dietary energetic level. Sustained homeostasis was observed in this setting, and even though size-sorting stress altered some hematological parameters, they were still within the range recognized as healthy. Choline was not effective in protecting the liver against hepatic steatosis, but was able to buffer some of the negative effects of stress under these rearing conditions.

Statement of Relevance: This research has been approved by the Ethics Committee of our Institution. Our team has been working with nutrition and fish health since 2000. According to the NRC (2011), only a few studies have been conducted to estimate the dietary nutrient requirements of farmed fish under intensive culture conditions. Moreover, a number of factors may affect the dietary and nutritional requirements of fish differentially in the laboratory and under intensive culture. For example, climatic conditions may fluctuate widely in the field, directly affecting physiological responses, hence nutritional requirements. Similarly, fish densities are much higher under intensive farming. Establishing the appropriate nutritional requirements in these settings must also consider the trade-off between growth performance and production costs. Based on this, we investigated the effect of different levels of digestible protein and digestible energy on growth performance and hematological responses of the Nile tilapia in a commercial fish farm in Brazil, where fish farmers are known to use diets with excessive levels of crude protein throughout fish culture and hepatic steatosis is often reported. Therefore, we also investigated the potential hepatic protective effect of choline against such conditions. Finally, we analyzed the health status, as measured by hematological parameters, of fish subjected to handling-induced stress procedures that are usual on fish farms.
\end{abstract}

(C) 2016 Elsevier B.V. All rights reserved.
* Corresponding author at: Faculdade de Medicina Veterinária and Zootecnia, UNESP, Univ. Estadual Paulista, Câmpus de Botucatu, C.P. 560, CEP 18618-970 Botucatu, SP, Brazil. E-mail address: ademircfjunior@hotmail.com (A.C. Fernandes).

\section{Introduction}

Dietary protein is one of the main factors that influence fish production and nitrogen waste into the water which, in excess, may impair fish 
growth and water quality under intensive fish farming (Mires et al., 1990, Tibbetts et al., 2000). Previous research conducted under laboratory conditions has estimated a dietary requirement of 25\% (El-Sayed and Gaber, 2005) and 27.5\% crude protein (Balarin and Haller, 1982) for tilapia. According to the NRC (2011), however, digestible protein to digestible energy ratio is a more rational way of expressing protein requirements. This is because dietary energy levels are also tightly linked to nutrient consumption. If energy is available in excess, it may impair nutrient consumption, whereas when in deficit protein can be catabolized as energy source (NRC, 2011). For the Nile tilapia, previous research conducted in the laboratory has determined optimal digestible protein:digestible energy ratios ranging from 21.4 to $32.7 \mathrm{~g} \mathrm{MJ}^{-1}$ depending on fish size (Trung et al., 2011). However, the digestible protein:digestible energy ratio has not been evaluated under field and stress conditions.

According to the NRC (2011), only a few studies have been conducted to estimate the dietary nutrient requirements of farmed fish under intensive culture conditions. Studies developed in these conditions are needed especially considering the constant environmental stress that fish are subjected to in intensive commercial settings. Moreover, a number of factors may affect the dietary and nutritional requirements of fish differentially in the laboratory and under intensive culture. For example, climatic conditions may fluctuate widely in the field, directly affecting physiological responses, hence nutritional requirements. Similarly, fish density is much higher, and fish management, such as sorting, is also more severe under intensive farming. Therefore, the nutritional demands of these fish are likely much higher, and may impair performance and immune responses, and increase susceptibility to pathogens when not met. On establishing the appropriate nutritional requirements in these settings the trade-off between growth performance and production costs must also be considered.

Several metabolic syndromes, such as hepatic steatosis, have been associated with nutritional disorders. Since choline plays an important role on the maintenance of cell structure, lipid transportation and phosphatidilcholine precursor, which is responsible for hepatic steatosis prevention, its dietary inclusion is necessary since fish cannot synthesize this compound in adequate amount (Ketola, 1976; Halver, 2002; McDowell, 1989; NRC, 2011).

In this study we investigate the effect of different levels of digestible protein and digestible energy on growth performance and hematological responses of the Nile tilapia in a commercial fish farm in Brazil, where fish farmers are known to use diets with excessive levels of crude protein throughout fish culture and hepatic steatosis is often reported. Therefore, we also investigated the potentially protective effect of choline (Ogino et al., 1970; Osol et al., 1982; Wilson and Poe, 1988) against hepatic steatosis, a recurrent problem in fish raised under intensive conditions. Finally, we analyze the health status, as measured by hematological parameters, of fish subjected to size-sorting stress procedures that are typical of commercial practice.

\section{Materials and methods}

The study is made of two phases. In phase I, fish received diets with different levels of digestible protein, digestible energy and with or without supplemented choline. Growth performance, fillet yield, visceral fat, liver lipid concentration and economical analyses were evaluated. In phase II, we compared fish physiological condition considering their health status, before and after sorting-induced stress.

\subsection{Study area (phases I and II)}

This study was developed to evaluate the growth performance, physiological response, and production cost of Nile tilapia in net cages fed diets containing levels of digestible protein, digestible energy, and choline for 119 days in the autumn and winter (9 March to 5 July). The research was carried out in the Fernandes Fish Farm, Canoas II reservoir, São Paulo State, Brazil (22 $56^{\prime} 41.47^{\prime \prime}$ S and 50¹0'39.06" W). This reservoir is located between São Paulo and Parana State. The water average temperature is $23.3 \pm 7^{\circ} \mathrm{C}$, with maximum and minimum temperatures of 30 and $16^{\circ} \mathrm{C}$, respectively.

\subsection{Fish and experimental procedure (phase I)}

Fish were stocked into ten $6 \mathrm{~m}^{3}(2.0 \times 2.0 \times 1.5 \mathrm{~m})$ net cages at a density of 2300 male Nile tilapia (Supreme Tilapia strain) per net cage during 25 days, in order to adapt to experimental conditions. Then, twelve thousand male Nile tilapia juveniles with an initial body weight of $148 \pm 6.7 \mathrm{~g}$ (mean $\pm \mathrm{SD}$ ) were randomly stocked into $801 \mathrm{~m}^{3}$ net cages $(1.0 \times 1.0 \times 1.0 \mathrm{~m})$ at a density of 150 fish per net cage (Ridha, 2006). The experimental design was a $5 \times 2 \times 2$ factorial design with five digestible protein (DP) levels $(24,26,28,30$, and $32 \% \mathrm{DP})$, two digestible energy levels (DE) (13.4 and $14.65 \mathrm{MJ} \mathrm{DE} \mathrm{kg}{ }^{-1}$ diet), and two choline levels (Cho) ( 0.0 and $1000 \mathrm{mg} \mathrm{kg}^{-1}$ diet) totalizing 20 treatments. All treatments were randomly distributed among net cages with four replicates per treatment. Fish were hand-fed two or three times daily, depending on the water temperature. Briefly, the amount of feed was previously weighed, and then distributed to each net cage using a boat. The feeding management took about $40 \mathrm{~min}$, in which the mortality was recorded.

At the beginning of the experiment the water temperature was $24^{\circ} \mathrm{C}$ (9 March); it gradually decreased to $21^{\circ} \mathrm{C}$ (4 May), reached $17^{\circ} \mathrm{C}$ on 4 June, and maintained until the end of the experiment (5 July, 2011). Therefore, the average water temperature was $20.5^{\circ} \mathrm{C}$, which is considered below ideal temperature for optimal growth and health (Lim and Webster, 2006). The amount of diet offered during the feeding trial considered the water temperature, as recommended for Nile tilapia (Lim and Webster, 2006). At above $21{ }^{\circ} \mathrm{C}$ fish were fed three times daily, and at lower temperatures twice daily. The average amount of feed fed to the fish was the same regardless of treatment (133.6 kg per net cage).

\subsection{Water quality (phase I)}

Water temperature, $\mathrm{pH}$, dissolved oxygen (DO), dissolved oxygen saturation (DOS), total dissolved solids (TDS), and total ammonia were measured every morning through a multi probe system (YSI Environmental, Yellow Spring, OH, USA). The average water temperature was $20.5{ }^{\circ} \mathrm{C} \pm 3.5$ and other water quality parameters were: $\mathrm{pH} 7.25 \pm 0.2 ;$ DO $7.23 \pm 0.2 \mathrm{mg} \mathrm{L}^{-1}$; DOS 76.0\% \pm 5.0 ; TDS $0.63 \pm$ $0.6 \mathrm{mg} \mathrm{L}^{-1}$; total ammonia $0.06 \pm 0.01 \mathrm{mg} \mathrm{L}^{-1}$; Secchi depth $3.67 \pm$ $0.5 \mathrm{~m}$; and cyanobacteria concentration $<0.1 \mathrm{ppb}$. These values were within the comfort range for the species (Boyd, 1996).

\subsection{Growth performance parameters (phase I)}

At the end of the experimental period (119 days) final biomass (FB), specific growth rate (SGR), feed conversion ratio (FCR), visceral fat (VF), and fillet yield (FY) were determined.

Where:

$\mathrm{FB}(\mathrm{g})=$ weight of all fish in the net cage;

$\operatorname{SGR}\left(\%\right.$ day $\left.^{-1}\right)=($ Ln final weight-Ln initial weight/total no.of the experimental days) $\times 100$

$\mathrm{FCR}=$ dry feed intake $(\mathrm{g}) /$ wet weight gain $(\mathrm{g})$;

$\mathrm{VF}(\%)=[$ visceral fat weight $(\mathrm{g}) \times 100] /$ fish weight $(\mathrm{g}) ;$ and

FY $(\%)=[$ weight of the fillet $(\mathrm{g}) \times 100] /$ fish weight $(\mathrm{g})$.

\subsection{Diets}

Two diets were formulated to contain 24 and 32\% of DP with 13.4 and $14.65 \mathrm{MJ} \mathrm{DE} \mathrm{kg}^{-1}$. Others diets were obtained by the dilution 
method. The nutritional requirements were based on Furuya (2010) and NRC (2011) (Table 1).

Composition of diets:

$26 \% \mathrm{DP} / 13.4 \mathrm{MJ} \mathrm{DE} \mathrm{kg}{ }^{-1}=75 \%$ of $24 \% \mathrm{DP} / 13.4+25 \%$ of $32 \% \mathrm{DP} / 13.4$ $26 \% \mathrm{DP} / 14.65 \mathrm{MJ} \mathrm{DE} \mathrm{kg} \mathrm{kg}^{-1}=75 \%$ of $24 \% \mathrm{DP} / 14.65+25 \%$ of $32 \% \mathrm{DP} / 14.65$ $28 \% \mathrm{DP} / 13.4 \mathrm{MJ} \mathrm{DE} \mathrm{kg} \mathrm{kg}^{-1}=50 \%$ of $24 \% \mathrm{DP} / 13.4+50 \%$ of $32 \% \mathrm{DP} / 13.4$ $28 \% \mathrm{DP} / 14.65 \mathrm{MJ} \mathrm{DE} \mathrm{kg} \mathrm{kg}^{-1}=50 \%$ of $24 \% \mathrm{DP} / 14.65+50 \%$ of $32 \% \mathrm{DP} / 14.65$ $30 \% \mathrm{DP} / 13.4 \mathrm{MJ} \mathrm{DE} \mathrm{kg}{ }^{-1}=25 \%$ de $24 \% \mathrm{DP} / 13.4+75 \%$ of $32 \% \mathrm{DP} / 13.4$ $30 \% \mathrm{DP} / 14.65 \mathrm{MJ} \mathrm{DE} \mathrm{kg}^{-1}=25 \%$ de $24 \% \mathrm{DP} / 14.65+75 \%$ of $32 \% \mathrm{DP} / 14.65$.

Each diet comprised two treatments: without supplemented and supplemented with choline chloride, which was added at the expense of corn, totalizing 20 treatments. The diets were processed at Leben Foods ${ }^{\circledR}$ (Macatuba, São Paulo, Brazil). All ingredients were ground until sieved at a mesh diameter of $1000 \mu \mathrm{m}$ and homogenized in a horizontal mixer and subsequently processed at $100-120{ }^{\circ} \mathrm{C}$ in a single screw industrial extruder (Tecnal ${ }^{\circledR}$, Ribeirão Preto, São Paulo, Brazil) with capacity to process $1500 \mathrm{~kg} \mathrm{~h}^{-1}$ and exited in a $2 \mathrm{~mm}$ die to obtain a $5.0 \mathrm{~mm}$ pellet. The diets were dried in horizontal dryer $\left(100-120^{\circ} \mathrm{C}\right)$, cooled, and packaged in raffia bags.

\subsection{Hematological assay (phases I and II)}

At the end of the feeding period (119 days), and the period prior to size-sorting stress, seven fish per treatment were randomly collected and anesthetized with benzocaine (100 $\left.\mathrm{mg} \mathrm{L}^{-1}\right)$. Blood was collected from the caudal vein using a tuberculin syringe, rinsed with an anticoagulant (3\% EDTA) (Barros et al., 2014).

Red blood cell (RBC) counts were determined by dilution and enumeration in a hemocytometer. Leukocyte differentiation was performed in blood extension stained with May-Grünwald-Giemsa-Wright according to Jain (1986). Differential counting was performed under a microscope at $100 \times$ in immersion oil. Two hundred cells were counted to establish percentages for each cellular component of interest.

Hemoglobin $(\mathrm{Hb})$ was determined by the cyanometahemoglobin colorimetric method using a commercial kit (Analisa Diagnóstica, Belo Horizonte, MG, Brazil) according to Collier (1944). The hematocrit (Ht) percentage was determined using the microhematocrit method described by Goldenfard et al. (1971). The total plasma protein (TPP) was measured using a manual Goldberg refractometer by breaking the microhematocrit capillary just above the leukocyte layer after the hematocrit reading (Hrubec and Smith, 2010). The mean corpuscular volume $[\mathrm{MCV}=(\mathrm{Ht} \times 10) / \mathrm{RBC}]$ and the mean corpuscular hemoglobin concentration $[\mathrm{MCHC}=(\mathrm{Hb} \times 100 / \mathrm{Ht}]$ were calculated according to Wintrobe (1934).

The albumin concentration (ALB) was determined by the bromocresol method using the commercial kit Albumina Analisa Diagnóstica ${ }^{\circledR}$ for colorimetric determination. The albumin:globulin ratio $(A / G)$ was determined using ALB and TPP values [Globulin = TPP ALB; A/G = ALB/Globulin] (Jain, 1986). The glucose (Gluc) concentration was determined using the Analisa Diagnóstica ${ }^{\circledR}$ commercial kit.

Table 1

Ingredients and chemical composition of experimental diets (on dry matter basis) ${ }^{*}$

\begin{tabular}{|c|c|c|c|c|c|c|c|c|c|c|}
\hline Ingredients ( $\mathrm{g} \mathrm{kg}^{-1}$ dry diet) & $24 / 13.4$ & $24 / 14.65$ & $26 / 13.4$ & $26 / 14.65$ & $28 / 13.4$ & $28 / 14.65$ & $30 / 13.4$ & $30 / 14.65$ & $32 / 13.4$ & $32 / 14.65$ \\
\hline Soybean meal & 178 & 212 & 244 & 277 & 310 & 342 & 375 & 407 & 441 & 472 \\
\hline Wheat middlings & 225 & 75 & 203 & 56 & 181 & 37 & 159 & 18 & 137 & 0 \\
\hline Poultry byproduct meal & 200 & 200 & 200 & 200 & 200 & 200 & 200 & 200 & 200 & 200 \\
\hline Corn & 368.9 & 440 & 326.5 & 395.6 & 284.3 & 350.9 & 242.9 & 306.5 & 200.6 & 261.1 \\
\hline L-Lysine & 3.1 & 2.8 & 2.3 & 2.1 & 1.6 & 1.4 & 0.8 & 0.7 & 0 & 0 \\
\hline DL-Methionine & 1.5 & 1.7 & 1.2 & 1.3 & 0.9 & 1 & 0.5 & 0.6 & 0.2 & 0.2 \\
\hline Tryptophan & 0.2 & 0.3 & 0.2 & 0.2 & 0.1 & 0.2 & 0.1 & 0.1 & 0 & 0 \\
\hline Threonine & 2.1 & 2 & 1.6 & 1.5 & 1.1 & 1 & 0.5 & 0.5 & 0 & 0 \\
\hline Poultry viscera oil & 0 & 45 & 0 & 45.1 & 0 & 45.3 & 0 & 45.4 & 0 & 45.5 \\
\hline $\mathrm{NaCl}$ & 5 & 5 & 5 & 5 & 5 & 5 & 5 & 5 & 5 & 5 \\
\hline Premix vit/min ${ }^{\mathrm{a}}$ & 13.3 & 13.3 & 13.3 & 13.3 & 13.3 & 13.3 & 13.3 & 13.3 & 13.3 & 13.3 \\
\hline Banox $^{\mathrm{b}}$ & 0.2 & 0.2 & 0.2 & 0.2 & 0.2 & 0.2 & 0.2 & 0.2 & 0.2 & 0.2 \\
\hline Moldzap $^{c}$ & 1 & 1 & 1 & 1 & 1 & 1 & 1 & 1 & 1 & 1 \\
\hline Choline chloride & 1.7 & 1.7 & 1.7 & 1.7 & 1.7 & 1.7 & 1.7 & 1.7 & 1.7 & 1.7 \\
\hline \multicolumn{11}{|c|}{ Chemical composition ( $\mathrm{kg}^{-1}$ dry diet) } \\
\hline Digestible energy $\left(\mathrm{MJ} \mathrm{kg}^{-1}\right)$ & 13.4 & 14.7 & 13.4 & 14.7 & 13.4 & 14.7 & 13.4 & 14.7 & 13.4 & 14.7 \\
\hline Digestible protein & 240 & 240 & 260 & 260 & 280 & 280 & 300 & 300 & 320 & 320 \\
\hline Crude protein ${ }^{\mathrm{d}}$ & 291 & 292.9 & 314.8 & 306.5 & 340.8 & 336.2 & 355.2 & 345.1 & 373.3 & 373.2 \\
\hline Crude fiber $^{\mathrm{d}}$ & 44.8 & 40.1 & 50.8 & 43.5 & 49.2 & 44.2 & 42.8 & 44.4 & 52.3 & 48.1 \\
\hline Ether extract ${ }^{d}$ & 22.5 & 90 & 20 & 82.1 & 21.9 & 81 & 25.3 & 81.8 & 29.3 & 81 \\
\hline Total calcium & 8.9 & 8.7 & 9 & 8.9 & 9.1 & 9 & 9.2 & 9.1 & 9.3 & 9.2 \\
\hline Available phosphorus & 6.4 & 6.2 & 6.4 & 6.3 & 6.5 & 6.3 & 6.5 & 6.4 & 6.6 & 6.4 \\
\hline Methionine & 5.4 & 5.5 & 5.4 & 5.5 & 5.4 & 5.5 & 5.4 & 5.4 & 5.4 & 5.4 \\
\hline Sulfur amino acids & 9.1 & 9.1 & 9.4 & 9.3 & 9.7 & 9.6 & 10 & 9.9 & 10.3 & 10.1 \\
\hline Lysine & 15.2 & 15.2 & 16.1 & 16.2 & 17.1 & 17.2 & 18.1 & 18.2 & 19 & 19.2 \\
\hline Tryptophan & 2.8 & 2.8 & 3.1 & 3.1 & 3.4 & 3.4 & 3.7 & 3.6 & 3.9 & 3.9 \\
\hline Threonine & 10.5 & 10.5 & 10.9 & 10.9 & 11.3 & 11.3 & 11.6 & 11.7 & 12 & 12.1 \\
\hline Choline ( $\mathrm{mg} \mathrm{kg}^{-1}$ ) & 1000 & 1000 & 1000 & 1000 & 1000 & 1000 & 1000 & 1000 & 1000 & 1000 \\
\hline $\mathrm{DP}: \mathrm{DE}^{\mathrm{e}}$ & 17.9 & 17.57 & 19.4 & 17.74 & 20.89 & 19.11 & 22.37 & 20.46 & 23.86 & 21.83 \\
\hline
\end{tabular}

a Premix vitamins and minerals (Mogiana Alimentos) - Guaranteed minimum levels per kilogram of diet: Folic Acid: 10 mg; Copper: 20 mg; Vit. B1: 32 mg; Vit. E: 250 UI; Vit. K3: 30 mg;

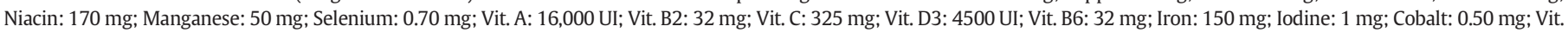
B12: $32 \mathrm{mcg}$; Calcium Pantothenate: $80 \mathrm{mg}$; Zinc: $150 \mathrm{mg}$; Biotin: $10 \mathrm{mg}$.

b Antioxidant.

c Antifungal.

d Analyzed values.

e Digestible protein and digestible energy ratio $\left(\mathrm{g} \mathrm{MJ}^{-1}\right)$.

* Ingredients and chemical composition of the diets supplemented with choline. 


\subsection{Size-sorting stress (phase II)}

After hematological profile and growth evaluation, fish were submitted to size-sorting stress. All fish were put on a fiberglass table where they were classified into three sizes. This procedure is routinely carried out in commercial fish farm in an attempt to restrict size ranges within rearing groups and thereby simplify feeding operations (Jobling and Reinsnes, 1987). This practice lasts for two days. Afterwards, blood samples were collected from seven anesthetized fish (benzocaine $100 \mathrm{mg} \mathrm{L}^{-1}$ ) per treatment from different net-cages to determine the same hematological parameters previously described.

\subsection{Lipid concentration and liver histological analysis (phase I)}

The livers from five anesthetized fish (benzocaine $100 \mathrm{mg} \mathrm{L}^{-1}$ ) per treatment were collected for lipid analysis. The livers were lyophilized and lipid concentration was determined according to AOAC methods (AOAC, 2000).

For histological analysis, fish were killed by a lethal dose of benzocaine solution ( $300 \mathrm{mg} \mathrm{L}^{-1}$ ). A postmortem internal examination of the liver was performed and liver samples from three fish per treatment were collected for histological examination, fixed in buffered formaldehyde (10\%). The samples were embedded in paraffin, sectioned at $5 \mu \mathrm{m}$ and stained with hematoxylin and eosin (HE).

Descriptive analysis was performed and the degenerative change was classified according to morphology based on Roberts and Rodger (1988). Scores in cellular degeneration were attributed as follows: $1=0$ to $25 \%$ of degenerate hepatocytes; $2=26$ to $50 \%$ of degenerate hepatocytes, $3=51$ to $75 \%$ of degenerate hepatocytes, and $4=$ more than $76 \%$ of degenerate hepatocytes. Histological changes were evaluated by a pathologist in a blind manner.

\subsection{Economic analysis (phase I)}

Prices for ingredients used in calculating the cost of diets were provided by Leben Food ${ }^{\circledR}$ (Macatuba, São Paulo, Brazil) based on the purchase price of the product by the company. The following values were used to calculate the cost of the experimental diets $\left(\$ \mathrm{~kg}^{-1}\right.$ diet, quoted in March 2012; $\$ 1.00=\mathrm{R} \$ 1.73)$ : soybean meal: $\$ 0.43 \mathrm{~kg}^{-1}$; wheat middlings: $\$ 0.25 \mathrm{~kg}^{-1}$; Poultry-byproduct meal: $\$ 0.58 \mathrm{~kg}^{-1}$; Corn: $\$ 0.29 \mathrm{~kg}^{-1}$; Poultry viscera oil: $\$ 1.22 \mathrm{~kg}^{-1}$; common salt: $\$ 0.22 \mathrm{~kg}^{-1}$; Premix vitamin/mineral: $\$ 2.89 \mathrm{~kg}^{-1}$; Moldzap: $\$ 2.72 \mathrm{~kg}^{-1}$; Banox: $\$ 4.83 \mathrm{~kg}^{-1}$, L-Lysine: $\$ 3.24 \mathrm{~kg}^{-1}$, DL-Methionine: $\$ 6.36 \mathrm{~kg}^{-1}$, L-Tryptophan: $\$ 28.73 \mathrm{~kg}^{-1}$, and L-Threonine: $\$ 4.05 \mathrm{~kg}^{-1}$. The cost of processing and bagging was included in the price of feed, with values of $\$ 0.14 \mathrm{~kg}^{-1}$ diet and $\$ 0.14 \mathrm{bag}^{-1}$, respectively. The value of transportation was added to the final product using $\$ 28.90$ per ton diet.

The following variables were used to calculate the economic analysis:

1. Feed intake: total feed supplied;

2. Final biomass $(\mathrm{kg})$ : weight of all the fish in the net cage at the end of the experiment;

3. Fillet yield (\%): [weight of the filet $(\mathrm{g}) \times 100$ ] / fish weight $(\mathrm{g})$; and

4. Weight of fillet $(\mathrm{kg})$ : Yield fillet $\times$ final biomass.

Other information was also used, such as: cost of juveniles, feed prices, cost of filleting, the selling price of whole fish, and selling price of the fillet. From this data set were estimated economic indicators for the marketing of whole fish and fillets, presented in \$/net cage (NC):

Gross revenue whole fish (GRwf) = selling price of the fish biomass $\left(\$ \mathrm{~kg}^{-1}\right) \times$ final biomass $(\mathrm{kg})$;

Gross revenue fillet $(\mathrm{GRf})=$ selling price $\times$ quantity of the fillet $(\mathrm{kg})$;

Production cost of whole fish (PCwf): (juvenile cost) + (feed intake $\times$ feed prices); and

Production cost of fillet $(\mathrm{PCf})=($ juvenile cost $)+($ feed intake $\times$ feed prices $)+$ (quantity of fillet $\times$ cost of filleting).
Other calculations included:

Benefit/Cost Ratio of whole fish (BCRwf) = GRwf / PCwf; and

Benefit/Cost Ratio of fillet (BCRf) = GRf / PCf.

The purchase price of $148 \mathrm{~g}$ juveniles ( $\$ 404.62$ per thousand), sale of whole fish $\left(\$ 2.08 \mathrm{~kg}^{-1}\right)$ and fillet $\left(\$ 9.25 \mathrm{~kg}^{-1}\right)$, as well as the cost of processing the fillets including labor, ice, and packaging $\left(\$ 1.16 \mathrm{~kg}^{-1}\right.$ of fillet) were indicated by the processing industry, based on values prevailing in March 2012.

\subsection{Statistical analysis}

Percentage data were arcsine transformed before statistical analysis. The variables were submitted to analysis of variance (ANOVA) $(\alpha<0.05)$; when significant differences were observed, a Tukey's test was applied $(\mathrm{P}<0.05)$ for comparison of means. When possible, regression analysis was performed using the SAS software (Statistical Analysis Systems Institute, USA) (Zar, 1999). The paired t-test was used for analyzing differences before and after size-sorting stress.

\subsection{Ethics statement}

All experimental procedures were approved by the Animal Ethics Committee of the Veterinary and Animal Science College, São Paulo State University (protocol 44/2010 - CEUA).

\section{Results}

\subsection{Growth performance and feed utilization}

Survival rate $(97.3 \pm 1.4 \%)$ was not affected by digestible protein, digestible energy, and choline. Our results showed main effects of both DP and DE, with a significant interaction between DP and DE for FB, FCR and FY $(P<0.05)$ (Table 2). Overall, the highest FB, and the best FCR values were achieved with lower protein content only when fish were fed higher energy diets. Generally, the higher the dietary protein content, the higher the FY for both energy levels (Fig. 1). Protein effects were linear for FY and quadratic for FB, and FCR (Fig. 2).

Specifically, fish fed $24 \%$ DP with $14.65 \mathrm{MJ} \mathrm{kg}^{-1}$ showed better FCR than fish fed 13.4 MJ DE kg-1. Moreover, fish fed 24 and 26\% DP with $14.65 \mathrm{MJ} \mathrm{kg}^{-1}$ showed higher FB than fish fed 13.4 MJ DE kg-1 $(\mathrm{P}<0.05)$. Within those fish fed lower energy diets $\left(13.4 \mathrm{MJ} \mathrm{DE} \mathrm{kg}{ }^{-1}\right)$,

Table 2

Mean values of initial biomass (IB), final biomass (FB), specific growth rate (SGR), feed conversion ratio (FCR), fillet yield (FY), visceral fat (VF), and liver lipid (LL) of Nile tilapia fed digestible protein (DP), digestible energy (DE), and choline (Cho) levels for 119 days.

\begin{tabular}{|c|c|c|c|c|c|c|c|}
\hline & IB (kg) & $\mathrm{FB}(\mathrm{kg})$ & SGR & FCR & $\mathrm{FY}(\%)$ & $\mathrm{VF}(\%)$ & LL (\%) \\
\hline \multicolumn{8}{|l|}{$D P(\%)$} \\
\hline 24 & 22 & 98.8 & 1.29 & 1.57 & 34.7 & 5.3 & $44.2^{\mathrm{b}}$ \\
\hline 26 & 22.7 & 101.5 & 1.28 & 1.51 & 35.4 & 4.7 & $27.7^{\mathrm{a}}$ \\
\hline 28 & 22.2 & 104.9 & 1.31 & 1.43 & 35.2 & 4.3 & $24.3^{a}$ \\
\hline 30 & 22 & 103.3 & 1.32 & 1.45 & 36.6 & 4.8 & $26.3^{\mathrm{a}}$ \\
\hline 32 & 22 & 98.4 & 1.30 & 1.55 & 36.5 & 4.3 & $26.3^{\mathrm{a}}$ \\
\hline \multicolumn{8}{|c|}{$D E\left(M J D E k^{-1}\right)$} \\
\hline 13.40 & 22.2 & 100.4 & 1.29 & 1.52 & 35.7 & $4.3^{b}$ & 30.1 \\
\hline 14.65 & 22.2 & 102.3 & 1.31 & 1.48 & 35.7 & $5^{a}$ & 29.4 \\
\hline \multicolumn{8}{|c|}{ Choline ( $\left.m g \mathrm{~kg}^{-1}\right)$} \\
\hline 0 & 22.3 & 101.5 & 1.30 & 1.5 & 35.9 & 4.6 & 28.6 \\
\hline 1000 & 22.1 & 101.2 & 1.30 & 1.5 & 35.5 & 4.8 & 30.9 \\
\hline $\mathrm{CV}(\%)$ & 5 & 3.31 & 3.64 & 3.87 & 2.48 & 25 & 24.4 \\
\hline \multicolumn{8}{|c|}{ Probability } \\
\hline DP & ns & $<0.0001$ & ns & $<0.0001$ & $<0.0001$ & ns & $<0.0001$ \\
\hline $\mathrm{DE}$ & ns & 0.0149 & ns & $<0.0052$ & ns & 0.0045 & ns \\
\hline DP*DE & ns & 0.0095 & ns & 0.0022 & 0.0469 & ns & ns \\
\hline
\end{tabular}

Mean values of four replicates, except liver lipid which is five replicates. The same superscript is not significantly different (Tukey $\mathrm{P}>0.05$ ). $\mathrm{CV}=$ coefficient of variation; Cho $=$ ns; $\mathrm{DP}^{*} \mathrm{Cho}=\mathrm{ns} ; \mathrm{DE}^{*} \mathrm{Cho}=\mathrm{ns} ; \mathrm{DP}^{*} \mathrm{DE}^{*} \mathrm{Cho}=\mathrm{ns} ; \mathrm{ns}=$ not significant. 


\section{Final biomass (kg)}

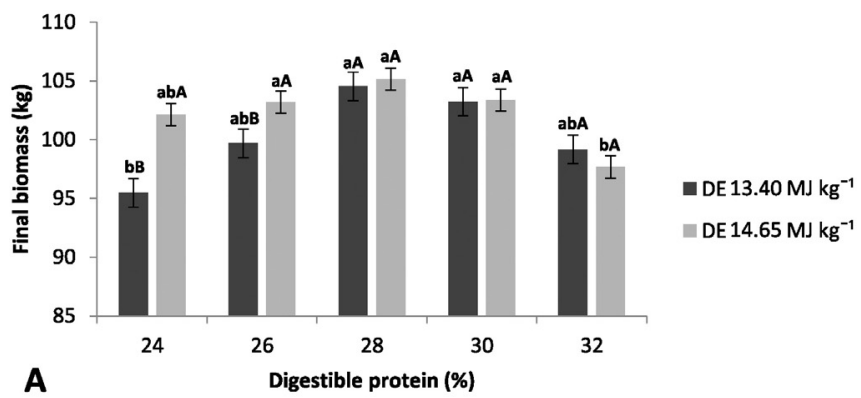

Feed conversion ratio

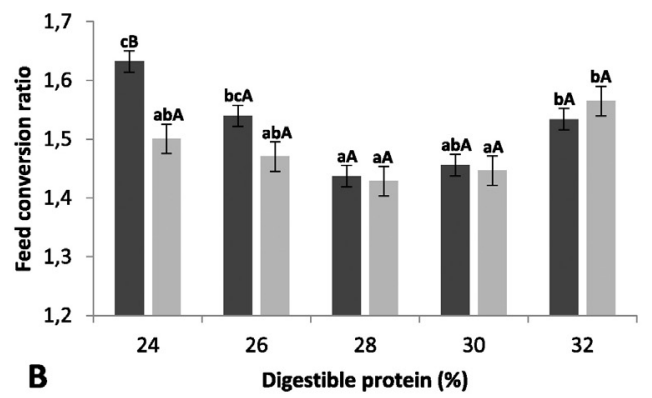

Fillet yield (\%)

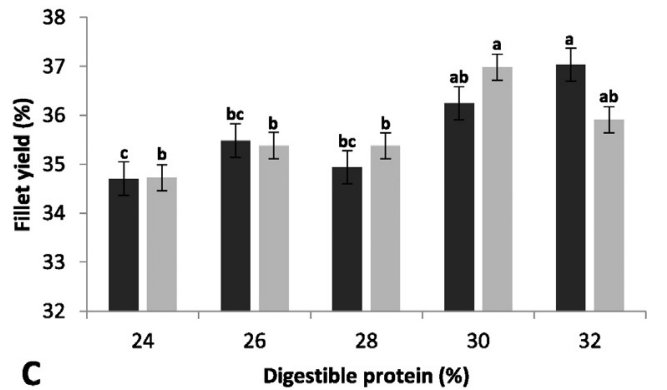

DE $13.40 \mathrm{MJ} \mathrm{kg}^{-1}$ DE $14.65 \mathrm{MJ} \mathrm{kg}^{-1}$

DE $13.40 \mathrm{MJ} \mathrm{kg}^{-1}$ DE $14.65 \mathrm{MJ} \mathrm{kg}^{-1}$

Fig. 1. A, B \& C. Final biomass (A), feed conversion ratio (B) and fillet yield (C). Mean values of eight replicates \pm standard deviation sharing the same lowercase superscript are not significantly different (Tukey $\mathrm{P}<0.05$ ) for digestible protein levels; mean values of eight replicates \pm standard deviation sharing the same uppercase superscript are not significantly different (Tukey $\mathrm{P}<0.05$ ) for digestible energy levels.

higher FB was achieved with 28 and $30 \%$ DP than with $24 \%$ DP $(\mathrm{P}<0.05)$.

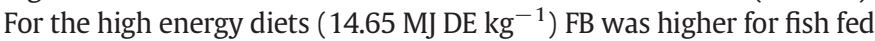
26,28 , and $30 \% \mathrm{DP}$ than for those fed $32 \% \mathrm{DP}(\mathrm{P}<0.05)$ (Fig. 1). The best FCR values were observed for fish fed $28 \% \mathrm{DP} / 13.4 \mathrm{MJ} \mathrm{kg}^{-1}$, whereas for $14.65 \mathrm{MJ} \mathrm{kg}^{-1}$, the best ratio was achieved with $24 \% \mathrm{DP}(\mathrm{P}<0.05)$. The analysis also showed that FY did not differ between dietary energy levels when protein content was fixed, but in lower energy fish fed $32 \%$ DP showed higher FY than those fed 24, 26, and 28\%, although it did not differ from $30 \%$ DP. However, for fish fed $14.65 \mathrm{MJ} \mathrm{kg}^{-1}, 30 \%$ DP diets showed higher FY than 24, 26, and 28\%, while it did not differ from $32 \%$ DP (Fig. 1).

3.2. Visceral fat deposition, lipid concentration, and histological analyses in the liver

VF was positively associated with $14.65 \mathrm{MJ} \mathrm{DE} \mathrm{kg}^{-1}$ diet. Independently of DE, the highest levels of liver lipid accumulation were observed with 24\% DP diets (Table 2). Moreover, macroscopic examination of the liver showed that alterations in color and consistency were observed only for fish fed this protein level. However, histological
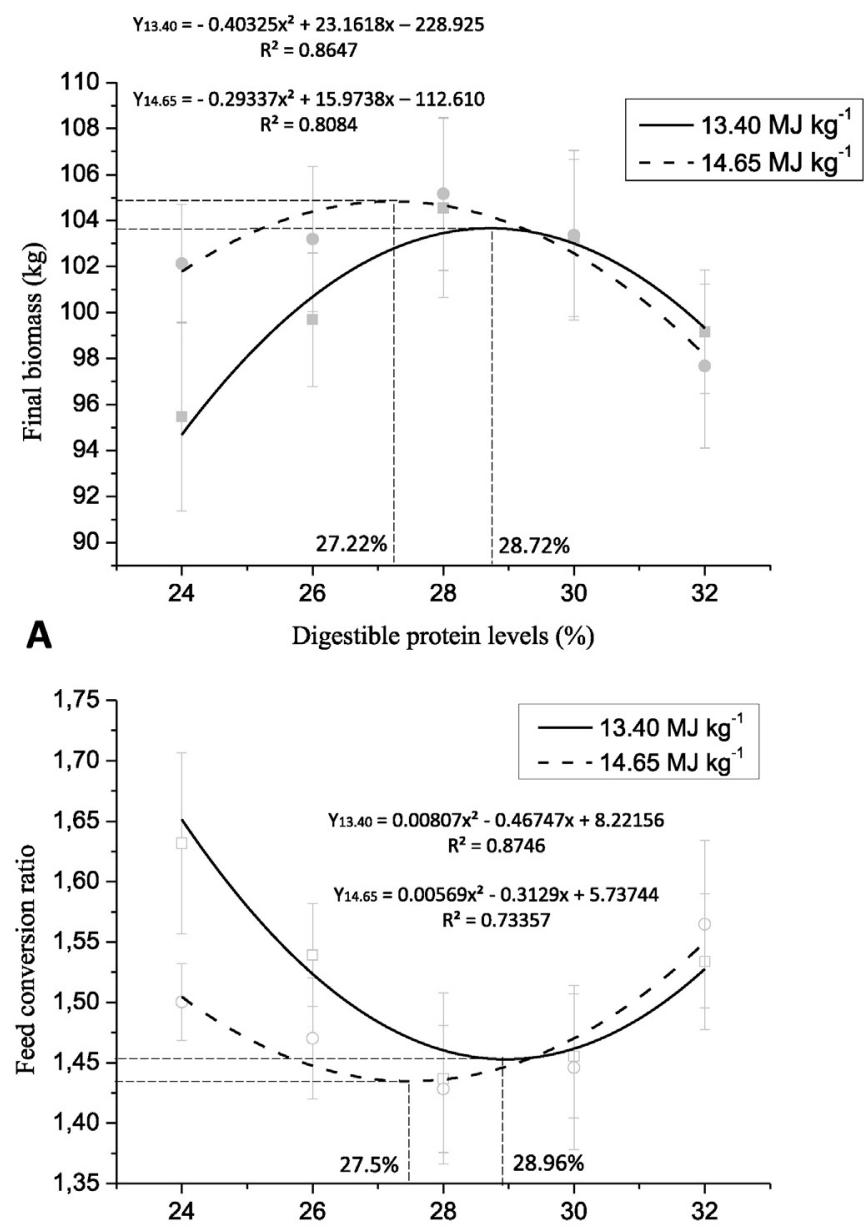

B

Digestible protein levels (\%)

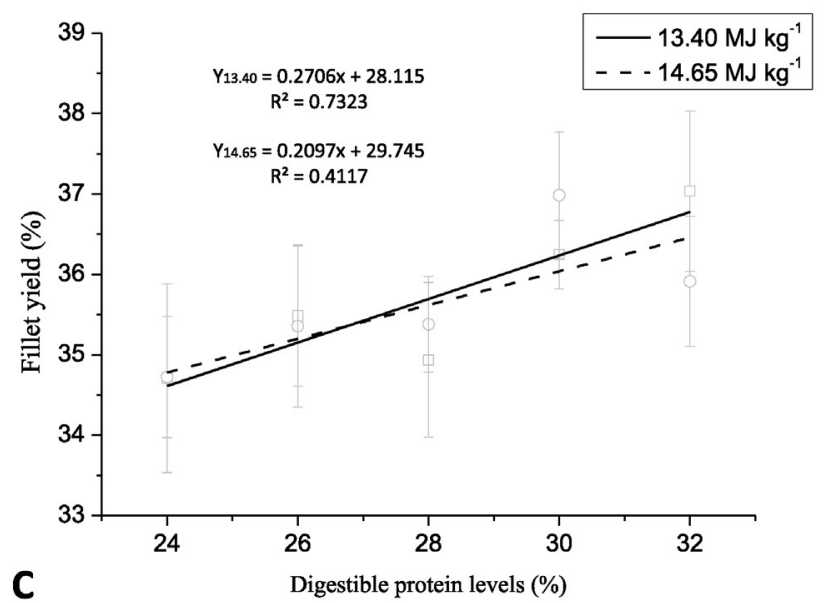

Fig. 2. Digestible protein requirement of Nile tilapia by quadratic relationship of digestible protein and digestible energy as a function of final biomass $(A)$ and feed conversion ratio (B), and linear relationship as a function of fillet yield (C). Each point is the mean of eight replicates.

alterations were observed in the liver for all diets, showing hydropic and fatty degeneration (Fig. 3).

\subsection{Hematological assay - size-sorting stress}

Generally, the results of the hematological assay showed alterations in RBC, MCV, Alb, A:G, and glucose, after stress (Tables 3 and 4). Fish fed diets with no choline and oil at $24 \%$ and $32 \%$ DP showed a decrease in $\mathrm{RBC}$ and an increase in MCV $(\mathrm{P}<0.05)$, and fish fed $26 \%$ DP showed a 

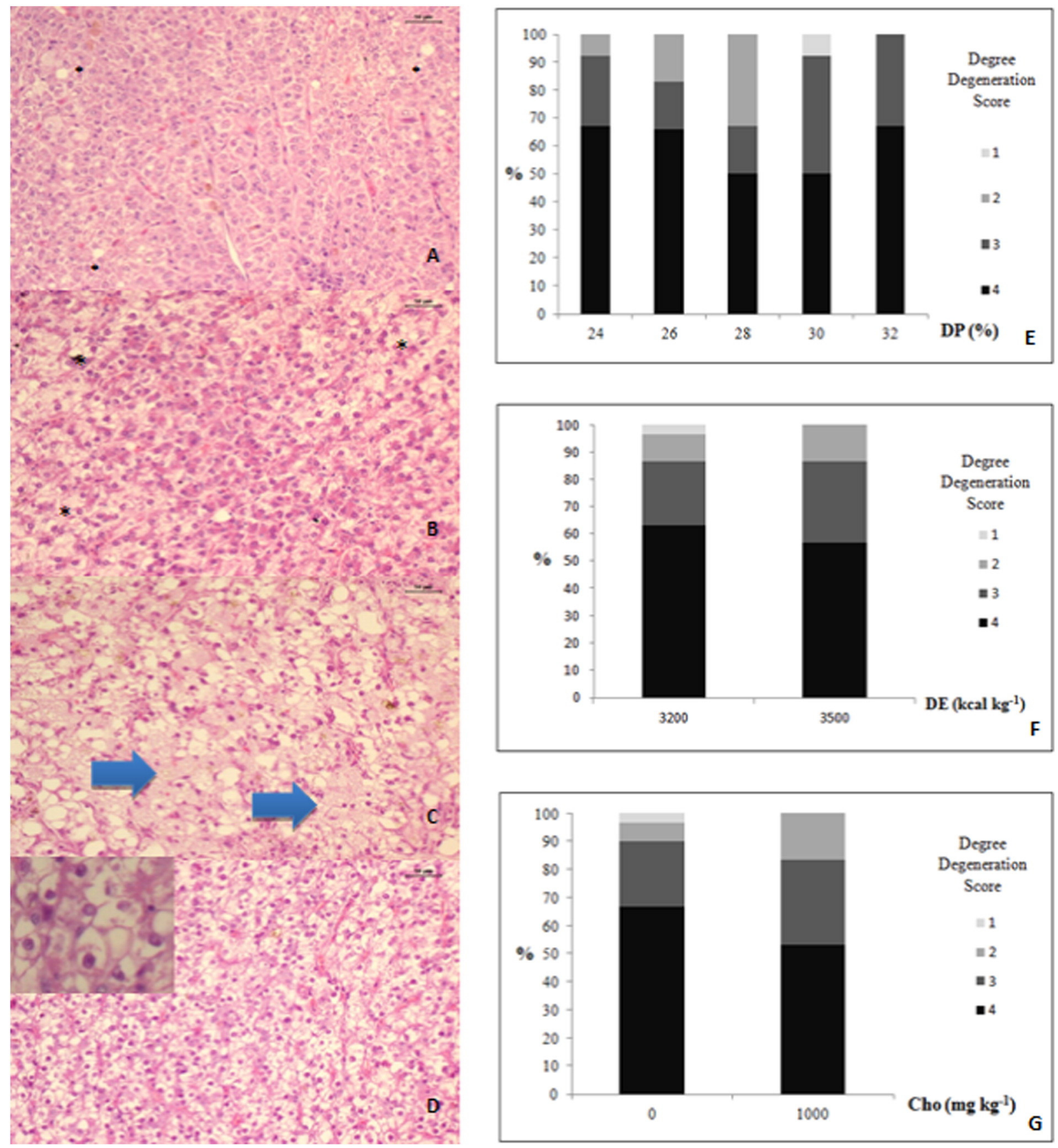

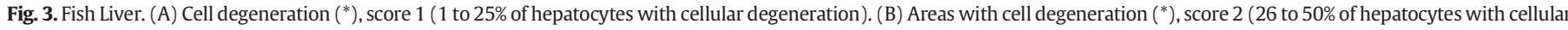

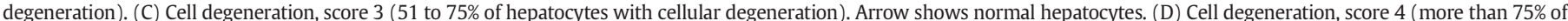

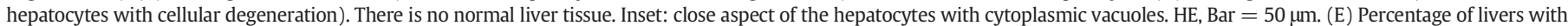
scores 1, 2, 3 and 4 considering digestible protein (DP) levels; (F) digestible energy (DE) levels and (G) choline (Cho) levels.

decrease in RBC. The only exception was an increase in MCV values with choline supplementation $(P<0.05)$ (Table 5 ) for fish fed $26 \%$ $\mathrm{DP} / 13.4 \mathrm{MJ} \mathrm{kg}^{-1}$. Similar effects were observed for albumin and A: $G$ ratio, which were also affected $(P<0.05)$ by size-sorting stress regardless of DP levels and choline supplementation. Glucose concentration was also affected, showing higher values $(\mathrm{P}<0.05)$ after stress, except for fish fed $24 \%$ DP diets. However, the comparison of values before and after size-sorting stress showed a DP effect $(\mathrm{P}<0.05)$ on Alb and A:G ratio for fish fed 26 and 28\% DP (Table 5). Size-sorting stress also determined a significant effect $(\mathrm{P}<0.05)$ on lymphocyte, neutrophil, and monocyte counts. Lymphopenia, neutrophilia, and an increase in monocyte count were observed for all treatments. However, leukocyte differentiation was not affected $(\mathrm{P}>0.05)$ by protein and energy levels, or by choline supplementation The mean values for lymphocytes, neutrophils, and monocytes, before and after size-sorting stress, were $97.01,1.48,1.51 \%$ and 76.33, 20.05, 3.49\%, respectively (Table 6).

\subsection{Economic analysis}

Economic analysis showed the highest profitability for whole fish production using $28 \% \mathrm{DP} / 13.4 \mathrm{MJ} \mathrm{kg}^{-1}$, with BCRwf of 1.52 . However, for fillet production, the highest BCRf (1.85) was obtained using 30\% DP/13.4 MJ (Table 7). 
Table 3

Hematological parameters of Nile tilapia fed digestible protein, digestible energy, and choline levels for 119 days and subjected to size-sorting stress.

\begin{tabular}{|c|c|c|c|c|c|c|c|c|c|c|c|}
\hline & & \multicolumn{2}{|c|}{$\begin{array}{l}\mathrm{RBC} \\
\left(10^{6} \mu \mathrm{L}^{-1}\right)\end{array}$} & \multicolumn{2}{|l|}{$\begin{array}{l}\mathrm{Ht} \\
(\%)\end{array}$} & \multicolumn{2}{|c|}{$\begin{array}{l}\mathrm{Hb} \\
\left(\mathrm{g} \mathrm{dL}^{-1}\right)\end{array}$} & \multicolumn{2}{|l|}{$\begin{array}{l}\text { MCV } \\
(\mathrm{fL})\end{array}$} & \multicolumn{2}{|l|}{$\begin{array}{l}\text { MCHC } \\
(\%)\end{array}$} \\
\hline & & Initial & Final & Initial & Final & Initial & Final & Initial & Final & Initial & Final \\
\hline \multirow[t]{5}{*}{ DP (\%) } & 24 & 2.16 & 1.93 & 25.96 & 26.30 & 6.88 & 7.45 & 122.44 & 138.39 & 26.49 & 28.24 \\
\hline & 26 & 2.11 & 1.95 & 25.73 & 26.19 & 6.86 & 6.93 & 123.82 & 134.00 & 26.73 & 26.63 \\
\hline & 28 & 2.05 & 1.91 & 24.93 & 24.80 & 6.56 & 7.02 & 124.16 & 131.65 & 26.33 & 28.24 \\
\hline & 30 & 2.09 & 1.79 & 24.15 & 23.98 & 6.44 & 6.73 & 119.65 & 136.14 & 26.37 & 28.24 \\
\hline & 32 & 1.96 & 1.82 & 23.73 & 24.54 & 6.28 & 6.72 & 124.14 & 136.11 & 26.54 & 27.40 \\
\hline \multirow[t]{2}{*}{$\mathrm{DE}\left(\mathrm{MJ} \mathrm{kg}^{-1}\right)$} & 13.40 & 2.10 & 1.85 & 25.15 & 24.92 & 6.71 & 6.92 & 121.64 & 135.39 & 26.69 & 27.85 \\
\hline & 14.65 & 2.05 & 1.91 & 24.67 & 25.36 & 6.50 & 7.02 & 124.13 & 135.11 & 26.30 & 27.67 \\
\hline \multirow[t]{3}{*}{ Choline ( $\mathrm{mg} \mathrm{kg}^{-1}$ ) } & 0 & 2.10 & 1.87 & 25.24 & 25.00 & 6.64 & 6.97 & 122.69 & 135.02 & 26.27 & 27.96 \\
\hline & 1000 & 2.05 & 1.89 & 24.60 & 25.28 & 6.57 & 6.97 & 123.08 & 135.49 & 26.71 & 27.56 \\
\hline & CV (\%) & 19.12 & 13.76 & 13.87 & 11.93 & 15.99 & 13.77 & 16.64 & 13.23 & 9.65 & 9.44 \\
\hline
\end{tabular}

Probability

Initial $\times$ final

0.0001

ns

ns

$<0.0001$

ns

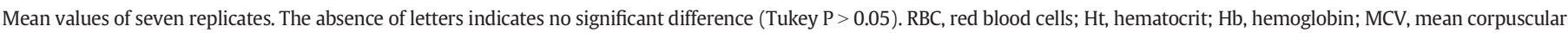

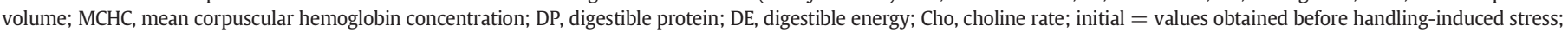

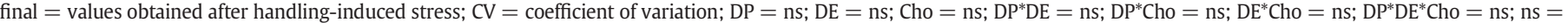
not significant.

\section{Discussion}

We sought to investigate the nutritional requirements of the Nile tilapia under intensive rearing conditions representative of those employed in commercial fish farms, as well as the putative protective effect of supplementation with choline on hepatic damage. To this end, we tested 20 diets including five levels of DP, two levels of DE, supplemented or not with choline and subjected fish to size-sorting stress. Differences in DP:DE ratio significantly affected growth performance. Moreover, although choline did not protect the liver against lipid accumulation, it was able to buffer some of the negative effects of stress.

The higher growth observed in diets containing low protein ( 24 and $26 \% \mathrm{DP}$ ) but high energy can be attributed to a protein sparing effect, as previously observed (De-Silva et al., 1992; Meyer and Fracalossi, 2004; NRC, 2011). To ensure the efficiency of low protein diets, the amount of energy supplied must be sufficient to meet energetic requirements, allowing the use of protein sources to sustain adequate growth. Accordingly, fish fed low energy diets used the protein fraction as energy source, as evidenced by the lower growth performance.

A poor growth performance was also achieved when the highest protein content was added to the diet, regardless of the energy level. Since, protein and free amino acid excess can be catabolized and excreted determining an unnecessary metabolic cost, we could infer that this nitrogen excretion may be associated with lower growth performance. Here, the best performance was achieved for the DP:DE ratios $21.45 \mathrm{~g} \mathrm{MJ}^{-1}$ (28.74\% DP/13.4 MJ DE kg$\left.{ }^{-1}\right)$ and $18.60 \mathrm{~g} \mathrm{MJ}^{-1}$ (27.25\% DP/14.65 MJ DE kg-1) at the low and high energy levels, respectively.

Consistent with the results of growth performance, our economic analysis showed that the best BCRwf is obtained with $28.0 \%$ $\mathrm{DP} / 13.40 \mathrm{MJ}$. In general, diets with 14.65 MJ DE were less profitable because of the high cost of oil, although they were efficient in terms of growth performance. Still, the use of oils as energy sources might be a cost-effective alternative depending on the market value of protein sources.

FY was higher at the highest DP contents ( 30 and 32\%), regardless of the energy level supplied. In our study the growth of muscle tissue was directly affected by the dietary protein, as previously reported by Li et al. (2000). Likewise, this result is consistent with previous research showing a positive association between fillet yield and amino acid content (Furuya et al., 2004). This response might be related to the high levels of lysine and threonine in diets with higher protein concentration, and may also explain the higher BCRf for the $30.0 \% \mathrm{DP} / 13.40 \mathrm{MJ}$ diet. The cost-benefit analyses indicated that the optimal dietary protein level relies on the final product desired. Regarding whole fish production,

Table 4

Plasmatic parameters of Nile tilapia fed digestible protein, digestible energy and choline levels for 119 days and subjected to size-sorting stress.

\begin{tabular}{|c|c|c|c|c|c|c|c|c|c|c|c|}
\hline & & \multicolumn{2}{|c|}{$\begin{array}{l}\text { TPP } \\
\left(\mathrm{mg} \mathrm{dL}^{-1}\right)\end{array}$} & \multicolumn{2}{|c|}{$\begin{array}{l}\text { Alb } \\
\left(\mathrm{mg} \mathrm{dL}^{-1}\right)\end{array}$} & \multicolumn{2}{|c|}{$\begin{array}{l}\text { Glob } \\
\left(\mathrm{mg} \mathrm{dL}^{-1}\right)\end{array}$} & \multicolumn{2}{|l|}{$A: G$} & \multicolumn{2}{|c|}{$\begin{array}{l}\text { Gluc } \\
\left(\mathrm{mg} \mathrm{dL}^{-1}\right)\end{array}$} \\
\hline & & Initial & Final & Initial & Final & Initial & Final & Initial & Final & Initial & Final \\
\hline \multirow[t]{5}{*}{$\mathrm{DP}(\%)$} & 24 & 3.67 & 3.83 & $0.73^{\mathrm{a}}$ & 1.05 & 2.90 & 2.77 & $0.26^{\mathrm{ab}}$ & 0.40 & 37.70 & 63.89 \\
\hline & 26 & 3.77 & 3.98 & $0.93^{\mathrm{b}}$ & 1.12 & 2.85 & 2.86 & $0.34^{\mathrm{b}}$ & 0.38 & 36.90 & 69.68 \\
\hline & 28 & 3.73 & 3.77 & $0.92^{\mathrm{b}}$ & 1.33 & 2.81 & 2.51 & $0.34^{\mathrm{b}}$ & 0.55 & 32.35 & 89.24 \\
\hline & 30 & 3.42 & 3.85 & $0.82^{\mathrm{ab}}$ & 1.26 & 2.65 & 2.60 & $0.32^{\mathrm{ab}}$ & 0.50 & 28.33 & 78.24 \\
\hline & 32 & 3.61 & 3.68 & $0.69^{a}$ & 1.11 & 2.96 & 2.61 & $0.24^{\mathrm{a}}$ & 0.43 & 31.69 & 91.82 \\
\hline \multirow[t]{2}{*}{$\mathrm{DE}\left(\mathrm{MJ} \mathrm{kg}^{-1}\right)$} & 13.40 & 3.66 & 3.76 & 0.84 & 1.12 & 2.89 & 2.64 & 0.30 & 0.44 & 32.81 & 80.49 \\
\hline & 14.65 & 3.62 & 3.88 & 0.81 & 1.24 & 2.78 & 2.72 & 0.30 & 0.47 & 34.14 & 74.47 \\
\hline \multirow[t]{3}{*}{ Choline ( $\mathrm{mg} \mathrm{kg}^{-1}$ ) } & 0 & 3.67 & 3.81 & 0.84 & 1.21 & 2.84 & 2.71 & 0.31 & 0.45 & 32.72 & 71.82 \\
\hline & 1000 & 3.62 & 3.83 & 0.80 & 1.14 & 2.83 & 2.65 & 0.29 & 0.45 & 34.28 & 82.40 \\
\hline & $\mathrm{CV}(\%)$ & 13.14 & 13.16 & 25.75 & 24.97 & 15.56 & 16.57 & 33.67 & 32.20 & 41.64 & 58.37 \\
\hline \multicolumn{12}{|l|}{ Probability } \\
\hline Initial $\times$ final & & ns & & $<0.0001$ & & ns & & $<0.0001$ & & $<0.0001$ & \\
\hline DP & & ns & ns & 0.0001 & ns & ns & ns & 0.0001 & ns & ns & ns \\
\hline
\end{tabular}

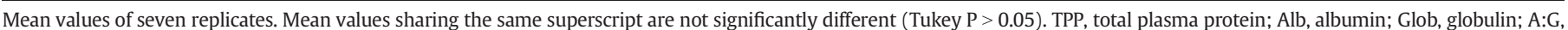

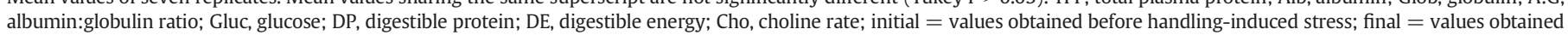
after handling-induced stress; $\mathrm{CV}=$ coefficient of variation; $\mathrm{DE}=\mathrm{ns} ; \mathrm{Cho}=\mathrm{ns} ; \mathrm{DP} * \mathrm{DE}=\mathrm{ns} ; \mathrm{DP}^{*} \mathrm{Cho}=\mathrm{ns} ; \mathrm{DE}^{*} \mathrm{Cho}=\mathrm{ns} ; \mathrm{DP}^{*} \mathrm{DE}{ }^{*} \mathrm{Cho}=\mathrm{ns} ; \mathrm{ns}=\mathrm{not}$ significant. 


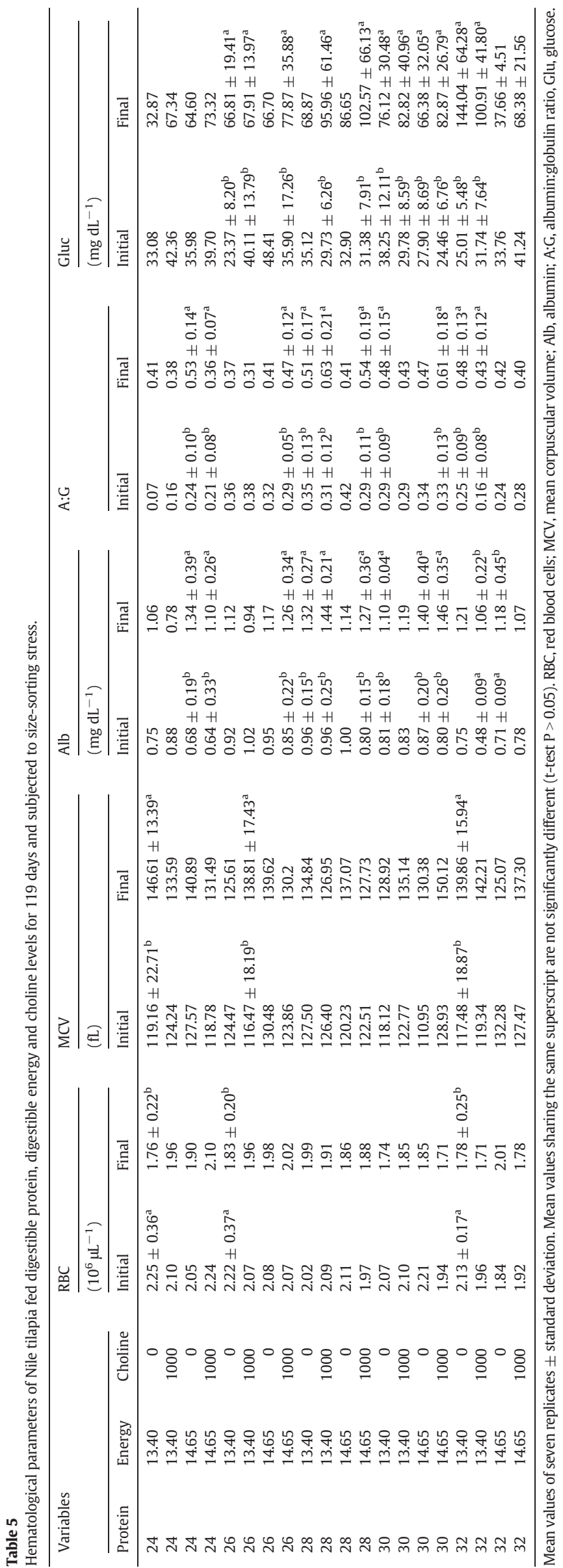

the highest profitability was reached with $28 \% \mathrm{DP} / 13.40 \mathrm{MJ} \mathrm{kg}^{-1}$. However aiming fillet production, the best result was achieved with $30 \% \mathrm{DP} / 13.40 \mathrm{MJ} \mathrm{kg}^{-1}$ emphasizing the importance of protein content for muscle synthesis, since protein deposition appears to be the main determinant of live weight gain in fish (Dumas et al. 2007). Our results also showed that significantly lower growth performance of fish fed 24 and 26\% DP diets offsets the lower feed costs and reduced profitability. Despite the fact that protein is the most costly macronutrient in aquaculture diets, in this study, the higher inclusion of crystalline amino acids on lower protein diets does not impact as much as oil inclusion, which clearly represents the main source of feed cost fluctuation, as described above.

The lowest protein level, at which concentration of carbohydrates in the diet was highest, induced lipid accumulation in the liver (44.16\%), as observed macroscopically and histologically. Overall, the percentage of lipids in the liver ranged from 24.32 to $44.16 \%$, a percentage higher than previously observed by some authors ( 3.9 to $16.0 \%$; Shiau and Lo, 2000; Peres et al., 2004; Shiau and Su, 2005), yet within the range (38.2 to 49.8\%) observed by Kasper et al. (2002). The high level of carbohydrate as an energy source might have led to fat deposition by lipogenesis once energy requirements were met, as previously reported (Helland and Grisdale-Helland, 1998; Gaye-Siessegger et al., 2006; Young et al., 2006; Leaver et al., 2008).

In contrast to previous findings (Ogino et al., 1970; Osol et al., 1982; Wilson and Poe, 1988), choline did not protect fish from fat accumulation in the liver. In fact, there was a high degree of degeneration in fish livers regardless of the diet, possibly due to the higher intake of food intake in commercial farming conditions such as those used in this study. In these settings, higher amounts of choline might be needed for a protective effect to be detected. Likewise, the high VF observed in fish fed high energy diets likely resulted from excessive energy not used for growth (Jauncey and Ross, 1982; Brown et al., 1992; Mohanta et al., 2009).

Fish dynamic equilibrium is constantly threatened by fluctuations in intrinsic and extrinsic factors, which may determine deleterious effects on growth, reproduction, and disease resistance. Although temperatures below the comfort zone along with high stock density may cause physiological stress, in this study these sources of stress, inherent to intensive culture system, did not affect fish hematological profile at the initial phase, as presented in Table 3, probably due to the gradual decrease in water temperature. Accordingly, hematological parameters obtained before the size-sorting stress procedure were close to those determined in the laboratory for this species (Hrubec and Smith, 2010; Barros et al., 2014), and under culture condition (Hrubec et al., 2000).

Hematopoietic tissue needs high and constant protein supply, so qualitative and quantitative cellular alterations have been described under inappropriate protein nutrition (Hrubec and Smith, 2010). It has also been showed that erythropoietin, the major physiological regulator of erythropoiesis, is closely related to protein level, mainly due to erythrocytes precursor synthesis. Protein dietary levels maintained erythropoiesis, even after size-sorting stress. However, in those diets without oil and choline, erythropoiesis was impaired, resulting in release of immature cells, following the stress challenge. This response is consistent with the observation that choline is a component of phospholipids in the fragile cellular membranes of tissue (Halver, 2002). Therefore, in our study, the size-sorting stress could have increased the demand for tissue oxygenation, resulting in the observed alterations in blood parameters. Indeed, anemia caused by choline deficiency was determined in rainbow trout (Kitamura et al., 1967). To our knowledge, however, few studies have analyzed the relationship between choline and erythropoiesis.

The increase of TPP and decrease of globulin levels found in our study reinforce the hypothesis that, regardless of the experimental diet, the acute size-sorting stress did not allow fish to reach homeostasis. Stress can also be evaluated by changes in albumin and glucose 
Table 6

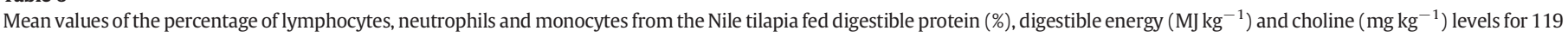
days and subjected to size-sorting stress.

\begin{tabular}{|c|c|c|c|c|c|c|c|c|}
\hline \multicolumn{3}{|c|}{ Variables } & \multicolumn{2}{|c|}{ Lymphocytes (\%) } & \multicolumn{2}{|c|}{ Neutrophils (\%) } & \multicolumn{2}{|c|}{ Monocytes (\%) } \\
\hline Protein & Energy & Choline & Initial & Final & Initial & Final & Initial & Final \\
\hline 24 & 13.40 & 0 & $95.13^{\mathrm{a}}$ & $81.88^{\mathrm{b}}$ & $2.75^{\mathrm{a}}$ & $15.5^{\mathrm{b}}$ & $2.13^{\mathrm{a}}$ & $2.63^{\mathrm{a}}$ \\
\hline 24 & 13.40 & 1000 & $95.75^{\mathrm{a}}$ & $84^{\mathrm{b}}$ & $2.5^{\mathrm{a}}$ & $12.88^{\mathrm{b}}$ & $1.75^{\mathrm{a}}$ & $3.13^{\mathrm{a}}$ \\
\hline 24 & 14.65 & 0 & $97.88^{\mathrm{a}}$ & $75.13^{\mathrm{b}}$ & $1^{\mathrm{a}}$ & $22.13^{\mathrm{b}}$ & $1.13^{\mathrm{a}}$ & $2.75^{\mathrm{a}}$ \\
\hline 24 & 14.65 & 1000 & $97.25^{\mathrm{a}}$ & $71.75^{\mathrm{b}}$ & $1.38^{\mathrm{a}}$ & $23.25^{\mathrm{b}}$ & $1.38^{\mathrm{a}}$ & $5^{b}$ \\
\hline 26 & 13.40 & 0 & $97.88^{\mathrm{a}}$ & $76.88^{\mathrm{b}}$ & $0.63^{\mathrm{a}}$ & $17.13^{\mathrm{b}}$ & $1.5^{\mathrm{a}}$ & $3.5^{\mathrm{a}}$ \\
\hline 26 & 13.40 & 1000 & $95.63^{\mathrm{a}}$ & $73.5^{\mathrm{b}}$ & $2.13^{\mathrm{a}}$ & $21.88^{\mathrm{b}}$ & $2.25^{\mathrm{a}}$ & $4.63^{\mathrm{a}}$ \\
\hline 26 & 14.65 & 0 & $97.25^{\mathrm{a}}$ & $75.88^{\mathrm{b}}$ & $1.38^{\mathrm{a}}$ & $21.38^{\mathrm{b}}$ & $1.38^{\mathrm{a}}$ & $2.75^{\mathrm{a}}$ \\
\hline 26 & 14.65 & 1000 & $96.75^{\mathrm{a}}$ & $71^{\mathrm{b}}$ & $1.88^{\mathrm{a}}$ & $25.88^{\mathrm{b}}$ & $1.38^{\mathrm{a}}$ & $3.13^{\mathrm{a}}$ \\
\hline 28 & 13.40 & 0 & $97^{\mathrm{a}}$ & $78.88^{\mathrm{b}}$ & $1.5^{\mathrm{a}}$ & $18^{\mathrm{b}}$ & $1.5^{\mathrm{a}}$ & $3.13^{b}$ \\
\hline 28 & 13.40 & 1000 & $96.38^{a}$ & $73.13^{\mathrm{b}}$ & $1.63^{\mathrm{a}}$ & $23.13^{b}$ & $2^{\mathrm{a}}$ & $3.75^{\mathrm{b}}$ \\
\hline 28 & 14.65 & 0 & $96.38^{a}$ & $77.75^{\mathrm{b}}$ & $1.38^{\mathrm{a}}$ & $18.63^{\mathrm{b}}$ & $2.25^{\mathrm{a}}$ & $3.63^{b}$ \\
\hline 28 & 14.65 & 1000 & $98.88^{a}$ & $73.13^{\mathrm{b}}$ & $0.63^{a}$ & $25^{\mathrm{b}}$ & $0.5^{\mathrm{a}}$ & $1.88^{\mathrm{b}}$ \\
\hline 30 & 13.40 & 0 & $96.75^{a}$ & $76.75^{\mathrm{b}}$ & $1.25^{\mathrm{a}}$ & $18^{\mathrm{b}}$ & $2^{\mathrm{a}}$ & $5.25^{\mathrm{b}}$ \\
\hline 30 & 13.40 & 1000 & $98^{a}$ & $81.38^{\mathrm{b}}$ & $0.88^{a}$ & $13.75^{\mathrm{b}}$ & $1.13^{\mathrm{a}}$ & $4.63^{b}$ \\
\hline 30 & 14.65 & 0 & $96.75^{a}$ & $75.38^{\mathrm{b}}$ & $2^{\mathrm{a}}$ & $20.75^{\mathrm{b}}$ & $1.25^{\mathrm{a}}$ & $3.88^{\mathrm{b}}$ \\
\hline 30 & 14.65 & 1000 & $96.25^{a}$ & $74.5^{\mathrm{b}}$ & $1.88^{\mathrm{a}}$ & $22.25^{\mathrm{b}}$ & $1.88^{\mathrm{a}}$ & $3.25^{\mathrm{a}}$ \\
\hline 32 & 13.40 & 0 & $96.38^{a}$ & $71.38^{\mathrm{b}}$ & $2.13^{\mathrm{a}}$ & $25.86^{\mathrm{b}}$ & $1.5^{\mathrm{a}}$ & $2.75^{\mathrm{a}}$ \\
\hline 32 & 13.40 & 1000 & $98.13^{a}$ & $73.88^{\mathrm{b}}$ & $0.88^{a}$ & $22^{\mathrm{b}}$ & $1^{\mathrm{a}}$ & $4.13^{b}$ \\
\hline 32 & 14.65 & 0 & $97.88^{\mathrm{a}}$ & $76.5^{\mathrm{b}}$ & $1^{\mathrm{a}}$ & $20.38^{b}$ & $1.13^{\mathrm{a}}$ & $3.13^{b}$ \\
\hline 32 & 14.65 & 1000 & $98^{\mathrm{a}}$ & $83.88^{\mathrm{b}}$ & $0.88^{\mathrm{a}}$ & $13.25^{\mathrm{b}}$ & $1.13^{\mathrm{a}}$ & $2.88^{\mathrm{a}}$ \\
\hline
\end{tabular}

Values are means of seven replicates. Means followed by the same letters within a row, no significant difference $(\mathrm{t}$-test $\mathrm{P}<0.05)$.

concentration (Nardocci et al., 2014). Increase of albumin levels may be related to the transport of fatty acids required as an energy source in stressful situations, especially in the liver and muscle (Kaneko et al., 1997). Our observation of higher glucose concentrations after stress further confirmed this effect, in line with the expectation that energy can be obtained by glycogenolysis for a short period (Sumpter, 1997), as previously observed (Carneiro and Urbinati, 2002; Evans et al., 2006; Falcon et al., 2007; Barros et al., 2014).

Higher susceptibility to disease is one of the outcomes of immunosuppression caused by stress. Handling, especially during winter time, is considered one of the major stressors for fish. As a consequence, increased fish susceptibility to opportunistic pathogens has been reported in winter by fish farmers. The changes in lymphocytes, neutrophils, and monocytes observed in this study after the size-sorting stress confirm this effect.

Lymphopenia after stress has been previously reported in fish by Barton and Iwama (1991). Here, lymphopenia was also observed, together with neutrophilia and increase in monocytes following handling.
Similar results were observed by Falcon et al. (2007); Barros et al. (2009), Under stress, the release of catecholamine and cortisol can cause constriction of the spleen, increasing blood flow and triggering the migration of leukocytes. The total number of white cells and lymphocytes may also decrease, together with phagocytic impairment of cellular functions (Barton and Iwama, 1991; McDonald and Milligan, 1992). Such a decrease in circulating lymphocytes might underlie the association between stress responses and disease outbreak due to the increased levels of plasma cortisol (Pickering and Pottinger, 1985). Likewise, Pickering (1986) reported that the decrease in lymphocytes may be related to fish resistance to pathogens. Here, the evaluation of leukocyte differentiation showed that size-sorting stress determined an increase of phagocytic cell production possibly aimed at the elimination of invading microorganisms, independently of the diet.

The cost-benefit analyses indicated that the optimal dietary protein level relies on the final product desired. Regarding whole fish production, the highest profitability was reached with $28 \% \mathrm{DP} / 13.40 \mathrm{MJ} \mathrm{kg}{ }^{-1}$. However aiming the fillet production, the best result was achieved

Table 7

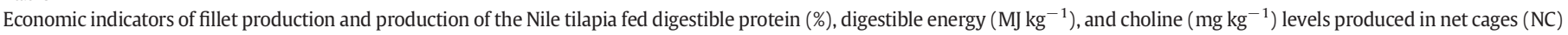
for 119 days.

\begin{tabular}{|c|c|c|c|c|c|c|c|c|c|}
\hline Diets & $\begin{array}{l}\text { Diet cost } \mathrm{kg}^{-1} \\
(\$)\end{array}$ & $\begin{array}{l}\text { Biomass } \mathrm{NC}^{-1} \\
\left(\mathrm{~kg} \mathrm{NC}^{-1}\right)^{\mathrm{a}}\end{array}$ & $\begin{array}{l}\text { CPwf } \\
\left(\$ \mathrm{NC}^{-1}\right)^{\mathrm{b}}\end{array}$ & $\begin{array}{l}\text { GRwf } \\
\left(\$ \mathrm{NC}^{-1}\right)^{\mathrm{c}}\end{array}$ & BCRwf $^{\mathrm{d}}$ & $\begin{array}{l}\text { Qt fillet } \mathrm{NC}^{-1} \\
\left(\mathrm{~kg} \mathrm{NC}^{-1}\right)^{\mathrm{e}}\end{array}$ & $\begin{array}{l}\mathrm{CPf} \\
\left(\$ \mathrm{NC}^{-1}\right)^{\mathrm{f}}\end{array}$ & $\begin{array}{l}\text { GRf } \\
\left(\$ N C^{-1}\right)^{g}\end{array}$ & $\mathrm{BCfR}^{\mathrm{h}}$ \\
\hline $24 / 13.40$ & 0.61 & 95.47 & 142.65 & 198.66 & 1.39 & 33.14 & 180.96 & 306.46 & 1.69 \\
\hline $24 / 14.65$ & 0.67 & 102.13 & 149.93 & 212.53 & 1.42 & 35.46 & 190.93 & 327.98 & 1.72 \\
\hline $26 / 13.40$ & 0.62 & 99.69 & 143.00 & 207.46 & 1.45 & 35.37 & 183.89 & 327.14 & 1.78 \\
\hline $26 / 14.65$ & 0.67 & 103.20 & 150.17 & 214.75 & 1.43 & 36.51 & 192.38 & 337.62 & 1.75 \\
\hline $28 / 13.40$ & 0.62 & 104.55 & 143.34 & 217.56 & 1.52 & 36.52 & 185.57 & 337.78 & 1.82 \\
\hline $28 / 14.65$ & 0.67 & 105.17 & 150.42 & 218.84 & 1.45 & 37.21 & 193.43 & 344.14 & 1.78 \\
\hline $30 / 13.40$ & 0.62 & 103.24 & 143.69 & 214.84 & 1.50 & 37.42 & 186.95 & 346.09 & 1.85 \\
\hline $30 / 14.65$ & 0.67 & 103.37 & 150.66 & 215.10 & 1.43 & 38.24 & 194.86 & 353.63 & 1.81 \\
\hline $32 / 13.40$ & 0.62 & 99.16 & 144.03 & 206.35 & 1.43 & 36.72 & 186.49 & 339.65 & 1.82 \\
\hline $32 / 14.65$ & 0.67 & 97.67 & 150.90 & 203.25 & 1.35 & 35.08 & 191.46 & 324.43 & 1.69 \\
\hline
\end{tabular}

a Biomass ( $\mathrm{kg}$ of fish per net cage ${ }^{-1}$ ).

b Cost of whole fish production (\$ net cages ${ }^{-1}$ ).

c Gross revenue of whole fish $\left(\$\right.$ cages $^{-1}$ ).

d Benefit/cost ratio of whole fish.

e Fish fillet per net cage ( $\mathrm{kg}_{\text {net }}$ cage $\left.^{-1}\right)$.

${ }^{\mathrm{f}}$ Cost of fillet production ( $\$$ net cage $\mathrm{e}^{-1}$ ).

g Gross revenue fillet $\left(\$\right.$ cages $\left.^{-1}\right)$.

$\mathrm{h}$ Benefit/cost ratio of fillet. 
with $30 \% \mathrm{DP} / 13.40 \mathrm{MJ} \mathrm{kg}^{-1}$ emphasizing the importance of protein content for muscle synthesis, since protein deposition appears to be the main determinant of live weight gain in fish (Dumas et al. 2007). Our results also showed that significantly lower growth performance of fish fed 24 and 26\% DP diets offsets the lower feed costs and reduced profitability. Despite the fact that protein is the most costly macronutrient in aquaculture diets, in this study, the higher inclusion of crystalline amino acids on lower protein diets does not reflect as much as oil inclusion, which clearly represents the main source of feed cost fluctuation.

In summary, this study showed that the best performance of Nile tilapia reared under intensive commercial farming conditions was achieved with DP:DE ratios of $21.45 \mathrm{~g} \mathrm{MJ}^{-1}$ (28.9\% DP/13.4 MJ DE kg-1) and $18.60 \mathrm{~g} \mathrm{MJ}^{-1}\left(27.5 \% \mathrm{DP} / 14.65 \mathrm{MJ} \mathrm{DE} \mathrm{kg}{ }^{-1}\right)$. The highest fillet yield was obtained with $30 \%$ DP, regardless of the dietary energetic level. Sustained homeostasis was observed in this setting, and even though size-sorting stress altered some hematological parameters, they were still within the range recognized as healthy. Choline was not effective in protecting the liver against hepatic steatosis, but was able to buffer some of the negative effects of stress under these rearing conditions. Overall, our study provides the best DP:DE ratio for Nile tilapia under intensive farming condition, which is essential to the fish feed industry, as well as to scientific community, especially considering health status and production costs. Based on unclear results for choline, higher levels should be tested, aiming at the appropriate dietary supplementation to avoid hepatic steatosis.

\section{Acknowledgments}

We are grateful to the Fundação de Amparo a Pesquisa do Estado de São Paulo - Fapesp (2009/52746-0) for scholarship support, and to Conselho Nacional de Desenvolvimento Científico e Tecnológico (470591/2010-2) for supporting this research. The authors would like to thank Dr. Jose Eurico Possebon Cyrino for his valuable comments on the earlier phase of this work and Dr. João Manoel Cordeiro Alves from Mogiana Alimentos for providing the premix.

\section{References}

AOAC (Associantion of Official Analytical Chemists), 2000. Official Methods of Analysis of the Association of Official Analytical Chemists. 17th ed. Association of Official Analytical Chemists, Gaithersburg, MD, USA.

Balarin, J.D., Haller, R.D., 1982. The intensive culture of tilapia in tanks, raceways and cages. In: Muir, J.F., Roberts, R.J. (Eds.), Recent Advances in Aquaculture. Croom Helm, London, pp. 265-356.

Barros, M.M., Falcon, D.R., Orsi, R.O., Pezzato, L.E., Fernandes Junior, A.C., Guimarães, I.G., Fernandes, A., Padovani, C.R., Sartori, M.M.P., 2014. Non-specific immune parameters and physiological response of Nile tilapia fed $\beta$-glucan and vitamin $C$ for different periods and submitted to stress and bacterial challenge. Fish and Shellfish Immunol. 39, 188-195.

Barros, M.M., Ranzani Paiva, M.J.T., Pezzato, L.E., Falcon, D.R., Guimarães, I.G., 2009. Hematological response and growth performance of Nile tilapia fed diets containing folic acid. Aquac. Res. 40, 895-903.

Barton, B.A., Iwama, G.K., 1991. Physiological changes in fish from stress in aquaculture with emphasis on the response and effects of corticosteroids. Annu. Rev. Fish Dis. 1, $3-26$.

Boyd, C.E., 1996. Water Quality in Ponds for Aquaculture. Shrimp Mart, Songkhla, Thailand.

Brown, M.L., Nematipour, G.R., Gatlin, D.M.I.I.I., 1992. Dietary protein requirement of juvenile sunshine bass at different salitinies. Prog. Fish Cult. 54, 148-156.

Carneiro, P.C.F., Urbinati, E.C., 2002. Transport stress in matrinxã, Brycon cephalus (Teleostei: Characidae), at different densities. Aquac. Int. 10, 221-229.

Collier, H.B., 1944. The standardization of blood haemoglobin determinations. Can. Med. Assist. J. 50, 550-552.

De-Silva, S.S., Gunasekera, R.M., Shim, K.F., 1992. Interactions of varying dietary-protein and lipid-levels in young red tilapia - evidence of protein sparing. Aquaculture 95, 305-318.

Dumas, A., de Lange, C.F.M., France, J., Bureau, D.P., 2007. Quantitative description of body composition and ratesof nutrient deposition in rainbow trout (Oncorhynchusmykiss). Aquaculture 273, 165-181.

El-Sayed, D.M.S.D., Gaber, M.M.A., 2005. Effect os dietary protein levels and feeding rates on growth performance, productions traits and body composition of Nile tilapia (Oreochromis niloticus), cultured in concrete tanks. Aquac. Res. 36, 163-171.
Evans, J.J., Pasnik, D.J., Brill, G.C., Klesius, P.H., 2006. Un-ionized ammonia exposure in Nile tilapia: toxicity, stress response, and susceptibility to Streptococcus agalactiae. N. Am. J. Aquac. 68, 23-33.

Falcon, D.R., Barros, M.M., Pezzato, L.E., Sampaio, F.G., Hisano, H., 2007. Physiological responses of Nile tilapia, Oreochromis niloticus, fed vitamin $C$ and lipid diets and submitted to low temperature stress. J. World Aquacult. Soc. 38, 287-295.

Furuya, W.M., 2010. Tabelas brasileiras para a nutrição de tilápias. Toledo: GFM. p. 100.

Furuya, W.M. Pezzato, LE. Barros, M.M., Pezzato, A.C., Furuya, V.R.B., Miranda, E.C., 2004 Use of ideal protein concept for precision formulation of amino acid levels in fishmeal-free dietas for juvenile Nile tilápia (Oreochromis niloticus). Aquac. Res. 35, 1110-1116.

Gaye-siessegger, J., Focken, U., Becker, K., 2006. Effect of dietary protein/carbohydrate ratio on activities of hepatic enzymes involved in the amino acid metabolism of Nile tilapia, Oreochromis niloticus (L.). Fish Physiol. Biochem. 32, 275-282.

Goldenfard, P.B., Bowyer, F.P., Hall, E., Brosius, E., 1971. Reproducibility in the hematology laboratory: the microhematocrit determination. Amer. J. Clinic Path, Baltimore 56, 35-39.

Halver, J.E., 2002. The vitamins. In: Halver, J.E., Hardy, R.W. (Eds.), Fish Nutrition. Academic Press, California, USA, pp. 62-141.

Helland, S.J., Grisdale-Helland, B., 1998. The influence of dietary carbohydrate and protein levels on energy and nitrogen utilization of Atlantic salmon in seawater. In: McCracken, E., Unsworth, F., Wylle, A.R.G. (Eds.), Energy Metabolism of Farmed Animals. CAB International, Oxon, pp. 391-394.

Hrubec, T.C., Cardinale, J.L., Smith, S.A., 2000. Hematology and plasma chemistry reference intervals for cultured tilapia (Oreochromis hybrid). Vet. Clin. Pathol. 29, 7-12.

Hrubec, T.C., Smith, S.A., 2010. Hematology of fishes. In: Douglas, J. (Ed.), Schalm's Veterinary Hematology, sixth ed. Blackwell Publishing Ltd., Singapore, pp. 994-1003.

Jain, N.C., 1986. Schalm's Veterinary Hematology. 4 ed. Lea \& Febiger, Philadelphia.

Jauncey, K., Ross, B., 1982. A Guide to Tilapia Feed and Feeding. Institute of Aquaculture, University of Sterling, Scothland.

Jobling, M., Reinsnes, T.G., 1987. Effect of sorting on size-frequency distributions and growth of Artic charr, Salvelinus alpinus L. Aquaculture 60, 27-31.

Kaneko, J.J., Harvey, J.W., Bruss, M.L., 1997. Clinical Biochemistry of Domestic Animals 5.Ed. Academic Press, New York, p. 932.

Kasper, C.S., White, M.R., BROWN, P.B., 2002. Betaine can replace choline in diets for juvenile nile tilapia, Oreochromis niloticus. Aquaculture 205, 119-126.

Ketola, H.G., 1976. Choline metabolism and nutritional requirement of lake trout (Salvelinus namaycush). J. Anim. Sci. Ott. 43, 474-477.

Kitamura, S., Suwa, T., Ohara, S., Nakagawa, K., 1967. Studies on vitamin requirements of rainbow trout. 2 . The deficiency symptoms of fourteen kinds of vitamin. Bull. Jpn. Soc. Sci. Fish. 33, 1120-1125.

Leaver, M.J., Bautista, J.M., Björnsson, B.T., Jönsson, E., Krey, G., Tocher, D.R., Torstensen, B.E., 2008. Towards fish lipid nutrigenomics: current state and prospects for FinFish Aquaculture. Rev. Fish. Sci. 16, 73-94.

Li, M.H., Bosworth, B.G., Robinson, E.H., 2000. Effect of dietary protein concentration on growth and processing yield of channel catfish Ictalurus punctatus. J. World Aquacult Soc. 31, 592-598.

Lim, C., Webster, D., 2006. Tilapia-biology, culture and nutrition. XIX. The Haworth Press New York, p. 678 ISBN-13.

McDonald, D.G., Milligan, C.L., 1992. Chemical properties of the blood. In: Hoar, W.S. Randall, D.J. (Eds.), Fish Fisiology 12A. Academic Press, London, pp. 55-133.

McDowell, L.R., 1989. Vitamins in Animal Nutrition - Comparative Aspects to Human Nutrition. Academic Press, San Diego, p. p486.

Meyer, G., Fracalossi, D.M., 2004. Protein requirement of jundia fingerlings, Rhamdia quelen, at two dietary energy concentrations. Aquaculture 240, 331-343.

Mires, D., Amit, Y., Avnimelech, S., 1990. Water quality in a recycled intensive fish culture system under field conditions. Isr. J. Aquacult. 42, 110-121.

Mohanta, K.N., Mohanty, S.N., Jena, J., Sahu, N.P., 2009. A dietary energy level of $14.6 \mathrm{MJ} \mathrm{kg}^{-1}$ and protein-to-energy ratio of $20.2 \mathrm{~g} \mathrm{MJ}^{-1}$ results in best growth performance and nutrients accretion in silver barb Puntius gonionotus fingerlings. Aquac. Nutr. 15, 627-637.

Nardocci, G., Navarro, C., Cortés, P.P., Imarai, M., Montoya, M., Valenzuela, B., Jara, P. Acuña-Castillo, C., Fernandez, R., 2014. Neuroendocrine mechanisms for immune system regulation during stress in fish. Fish Shellfish Immunol. 40, 531-538.

NRC (NATIONAL RESEARCH COUNCIL), 2011. Nutrient requirements of fish and shrimp. National Academic Press, Washington, D.C., p. 376.

Ogino, C., Uki, N., Watanabe, T., Lida, Z., Ando, K., 1970. B vitamin requirements of carp. IV. Requirement for choline. Bull. Jpn. Soc. Sci. Fish. 36, 1140-1146.

Osol, A., Chase, S.W., Francis, C.C., Nelhaus, G., Princhard, R.W., Richardson, R.E., Wenger N.K., 1982. Blakiston's Pocket Medical Dictionary. third ed. McGraw-Hill Book Company, New York, p. 1169.

Peres, H., Lim, C., Klesius, P., 2004. Growth, chemical composition an resistance to Streptococcus iniae challenge of juvenile Nile tilápia (Oreochromis niloticus) fed graded levels of dietary inositol. Aquaculture 235, 423-432.

Pickering, A.D., 1986. Changes in blood cell composition of the brow trout, Salmo trutta L. during the spawning season. J. Fish Biol. 29, 335-347.

Pickering, A.D., Pottinger, T.G., 1985. Cortisol can increase the susceptibility of brown trout, Salmo trutta, to disease without reducing the white blood cell count. J. Fish Biol. 27, 611-619.

Ridha, M.T., 2006. Comparative study of growth performance of three strains of Nile tilapia, Oreochromis niloticus, L. at two stocking densities. Aquac. Res. 37, 172-179.

Roberts, R.J., Rodger, H.D., 1988. The pathophysiology abd systemic pathology of Teleosts In: Roberts, R.J. (Ed.), Fish Pathology, Chapter 3. Elselvier, pp. 55-132.

Shiau, S.Y., Lo, P.S., 2000. Dietary choline requirements of juvenile hybrid tilapia, Oreochromis niloticus x 0 . aureus. J. Nutr. 1, 100-103. 
Shiau, S.Y., Su, S.L., 2005. Juvenile tilapia (Oreochromis niloticus x O. aureus) requires dietary myo-inositol for maximal growth. Aquaculture 243, 273-277.

Sumpter, J.P., 1997. The endocrinology of stress. In: Iwana, G.K., Pickering, A.D., Sumpter, J.P., Schreck, C.B. (Eds.), Fish Stress and Health in Aquaculture. University Press, Cambridge, pp. 95-118.

Tibbetts, S.M., Call, S.P., Anderson, D.M., 2000. Dietary protein requirement of juvenile American eel (Anguilla rostrata) fed pratical diets. Aquaculture 186, 145-155.

Trung, D.V., Diu, N.T., Hao, N.T., Glencross, B., 2011. Development of a nutritional model to define the energy and protein requirements of tilapia, Oreochromis niloticus. Aquaculture $320,69-75$.
Wilson, R.P., Poe, W.E., 1988. Choline nutrition of fingerling channel catfish. Aquaculture $68,65-71$.

Wintrobe, M.M., 1934. Variations in the size and hemoglobin content of erythrocytes in the blood of various vertebrates. Folia Haematol. Leipzig 51, 32-49.

Young, A., Morris, P.C., Huntingford, F.A., Sinnott, R., 2006. Replacing fish oil with preextruded carbohydrate in diets for Atlantic salmon, Salmo salar, during their entire marine grow-out phase: effects on growth, composition and color. Aquaculture $253,531-546$.

Zar, J.H., 1999. Biostatistical Analysis. 4ª̣ed. Prentice-Hall, Inc., New Jersey, . 663. 